\title{
The Value of Touch Imprint Cytology of Core Needle Biopsy in the Diagnosis of Spinal Lesions
}

\author{
Omurga Kor İğne Biyopsilerinde Imprint Sitolojisinin Değeri
}

\author{
Irem ONUR PAKER ${ }^{1}$, Murat SEZAK², Basak DOGANAVSARGIL ${ }^{2}$, Mehmet ZILELI ${ }^{3}$ Fikri OZTOP² \\ ${ }_{1}^{1}$ Ankara Diskapi Yildirim Beyazit Training and Research Hospital, Department of Pathology, Ankara, Turkey \\ ${ }^{2}$ Ege University, Faculty of Medicine, Department of Pathology, Izmir, Turkey \\ ${ }^{3}$ Ege University, Faculty of Medicine, Department of Neurosurgery, Izmir, Turkey
}

Correspondence address: Irem ONUR PAKER / E-mail: iremonur@yahoo.com

\begin{abstract}
AIM: We aimed to investigate the contribution of the touch imprint cytology (TIC) of core needle biopsies (CNBs) to the diagnosis in spinal lesions.

MATERIAL and METHODS: Sixty cases with spinal CNB and TIC were included in the study. Hematoxylin and Eosin (H\&E) and May-GrunwaldGiemsa (MGG) stained TIC slides and CNB of each case were blindly reevaluated by two pathologists. TIC and CNB findings were categorized as follows: 1-Nondiagnostic 2- Benign nonneoplastic 3- Benign neoplastic 4- Malignant 5-Malignant lesions that can be typed.

RESULTS: TIC and CNBs were nondiagnostic in $62 \%$ and $45 \%$ of all cases, respectively. Malignancy could be identified and typed in $23 \%$ of imprint preparations and $35 \%$ of CNBs. When TIC and CNB diagnosis were compared, it was seen that diagnostic categories were just the same in $70 \%$ of the cases. In $37 \%$ of the cases benign and malignant groups could be distinguished. In $20 \%$ of the cases diagnostic categories were totally different.

CONCLUSION: The percentage of the nondiagnostic material in CNBs can reach up to 45\%. The findings in TIC and CNBs were compatible with each other. We observed that TIC was diagnostic on its own especially in carcinoma metastasis and contributed to the assessement of cytologic detail in hematologic malignancies.
\end{abstract}

KEYWORDS: Imprint, Core needle biopsy, Cytology, Spine

öz

AMAÇ: Çalışmamızda omurga kor iğne biyopsilerinde (KiB) imprint sitolojisinin (IS) tanıya katkısını araştırmak amaçlandı.

YÖNTEM ve GEREÇLER: Omurga KIB ve is bulunan 60 olgu çalışmaya alındı. Her olgunun Hematoksilen-Eozin (H\&E) ve May-GrunwaldGiemsa (MGG) boyalı imprint preparatları ile biyopsi materyalleri, 2 patolog tarafından tanılara kör olarak yeniden değerlendirildi. ís'de izlenen hücresel elemanlar ile biyopsilerde izlenen bulgular; 1: Tanı için yetersiz 2: Benign nonneoplastik lezyonlar 3: Benign neoplastik lezyonlar, 4: Malign lezyonlar, 5: Tip tayini yapılabilen malign lezyonlar olarak gruplandırıldı. IS'nin tanıya katkısı ve biyopsi ile aralarındaki uyum istatistiksel olarak kappa korelasyon analizi ile araştırıldı.

BULGULAR: Imprintlerin ve biyopsilerin sırasıyla \%62'si ve \%45'inde bulgular tanı için yetersizdi ancak imprintlerin \%23'ünde, biyopsilerin \% 35'inde malignitenin tanınabildiği ve alt tip tayini yapılabildiği görüldü. ís ve KiB tanıları karşılaştıııldı̆ında olguların \%70'inde, tanı kategorilerinin birebir aynı olduğu, \%37'sinde benign ve malign grupların ayırtedilebildiği, \%20'sinde ise tanı kategorilerinin tamamen farklı olduğu gözlendi. H\&E ve MGG boyalı imprintler arasında ise anlamlı bir fark izlenmedi.

SONUÇ: Omurga KiB'lerinde nondiagnostik materyal oranı \%45'e ulaşabilmektedir. İs'nin biyopsi bulgularılyla uyumluluk gösterdiği, özellikle karsinom metastazlarında tek başına diagnostik olduğu, hematolojik malignitelerde hücresel detayın değerlendirilmesine katkıda bulunduğu gözlenmiş, MGG ile boyanan yaymaların, kondroid matriksin ve nükleer detayın değerlendirilmesine ek bir katkı sağladığı görülmüştür.

ANAHTAR SÖZCÜKLER: İmprint, Kor iğne biyopsisi, Sitoloji, Omurga

\section{INTRODUCTION}

Spine is one of the most important area of the body where metastatic tumors being in the first place and tumors of bone or spinal cord and sheaths are seen (3). In the diagnosis of the spinal lesions, clinical findings and radiologic evaluation are helpful but histopathologic examination is the gold standard. In spinal lesions, the accuracy of percutaneous CNB is reported to be between $65-100 \%(12,18,1,5,10)$. Particularly percutaneous CNB is favored over open biopsy because it is cheaper, painless and has a low complication rate $(10,14$, $13,6,15,11,7,17)$. In our study, we aimed to investigate the contribution of TIC of CNB to the diagnosis of spinal lesions.

\section{MATERIAL and METHODS}

We performed a retrospective analysis of cases which had both spinal CNB and TIC from the archives of Department of Pathology, School of Medicine, University of Ege between 
1999 and 2008. Hematoxylin and Eosin (H\&E) and MayGrunwald-Giemsa (MGG) stained TIC slides and CNB material of each case were blindly reevaluated by two different pathologists.

Cytologic findings seen in TIC slides and CNBs were categorized as follows:

\section{Category 1- Nondiagnostic:}

In CNB: the presence of blood or normal anatomic elements; muscle, adipose tissue, connective tissue, bone, cartilage as well as cells and tissues belonging to the intervertebral disc only

In TIC: the presence of blood only or the absence of cells

Category 2- Benign nonneoplastic lesions

Category 3- Benign neoplastic lesions

Category 4- Malignant lesions

Category 5- Malignant lesions that can be typed.

The contribution of TIC to the diagnosis and the concordance between the cytologic and histopathologic results were evaluated using kappa correlation analysis.

\section{RESULTS}

Between 1999 and 2008, we found 60 cases which had both spinal CNB and TIC in the archives of Department of Pathology, School of Medicine, University of Ege. Out of 60 patients, 33 were female and 27 were male. The ages of the patients ranged between 15 and 84 (mean=59).

Of 60 CNBs, 45\% ( $n=27)$ were nondiagnostic, 17\% $(n=10)$ benign (7 nonneoplastic, 3 neoplastic) and 38\% ( $n=23)$ malignant ( $n=2$ malignant NOS, $n=21$ malignant, typed). We could not reach the final diagnosis of cases with nondiagnostic
CNB, except for one case with a diagnosis of metastatic carcinoma. TIC results were nondiagnostic in $60 \%(n=36)$, benign in $8 \%(n=5)$, malignant in $32 \%(n=19)$. The correlation between TIC and CNB diagnosis are shown in Table I.

Of 10 cases with benign CNB, 6 had inflammation, 2 giant cell tumor, 1 aneurysmal bone cyst and 1 change related to fracture. Of these cases, 6 were nondiagnostic and 4 were benign on TIC (Table II). Aneurismal bone cyst and giant cell tumor (Figure 1A,B) cases were diagnosed as benign on TIC but the cytologic distinction between neoplastic and nonneoplastic lesion could not be made.

Of 23 cases with malignant diagnosis on $C N B, 16$ were metastatic carcinoma (Figure 2A,B), 4 plasmacytoma, 1 chordoma, 1 lymphoma, 1 Ewing sarcoma. Of all malignant cases, $78 \%(n=18)$ received malignant diagnosis on TIC and $57 \%(n=13)$ could be cytologically typed (Table III). Most of the malignant cases $(70 \%)$ were metastatic carcinoma. Of all metastatic carcinoma cases, malignancy was identified in $87 \%$ and type could be determined in $81 \%$. There was 1 false negative case which was hypocellular and showed multinucleated giant cells in cytology. It was thought to be a giant cell tumor but turned out to be a diffuse large $B$ cell lymphoma in CNB. There was no false positive case.

When TIC and CNB diagnosis were compared, it was seen that diagnostic categories were just the same in $70 \%(n=42)$ of the cases; in $37 \%(n=22)$ benign and malignant groups could be distinguished; in 20\% ( $n=12$ ) diagnostic categories were totally different (kappa value: 0.497 ).

In the diagnosis of the spinal lesions, the accuracy, sensitivity, specificity, negative predictive value and positive predictive value of TIC were $96 \%, 95 \%, 100 \%, 80 \%, 100 \%$, respectively.

In terms of diagnosis, there was no significant difference between H\&E and MGG stained preparations (kappa

Table I: Correlation Between TIC and CNB Diagnosis in Spinal Lesions

\begin{tabular}{|l|c|c|c|c|}
\hline TIC diagnosis & \multicolumn{5}{|c|}{ CNB diagnosis } \\
\hline & Nondiagnostic & Benign & Malignant & Total \\
\hline Nondiagnostic & 26 & 6 & 4 & 36 \\
\hline Benign & 0 & 4 & 1 & 5 \\
\hline Malignant & 1 & 0 & 18 & 19 \\
\hline Total & 27 & 10 & 23 & 60 \\
\hline
\end{tabular}

Table II: Categorization of TIC Diagnosis of Benign Spinal Lesions

\begin{tabular}{|l|c|c|c|c|c|c|}
\hline CNB diagnosis & \multicolumn{7}{|c|}{ Number of cases in TIC diagnostic categories } \\
\hline & Category 1 & Category 2 & Category 3 & Category 4 & Category 5 & Total \\
\hline Inflammation & 5 & 1 & 0 & 0 & 0 & 6 \\
\hline Giant cell tumor & 1 & 1 & 0 & 0 & 0 & 2 \\
\hline Aneurysmal bone cyst & 0 & 1 & 0 & 0 & 0 & 1 \\
\hline Change related to fracture & 0 & 1 & 0 & 0 & 0 & 1 \\
\hline Total & 6 & 4 & 0 & 0 & 0 & 10 \\
\hline
\end{tabular}


value: 0,879). However, it was observed that MGG stained preparations provided a contribution to the evaluation of the chondroid matrix and nuclear detail.

\section{DISCUSSION}

Percutaneous needle biopsy of the spine was first defined by Ball in 1934 (2). The complication rate of this method is low in the lesions of the spine which is a difficult anatomic area because of the surrounding blood vessels, nerves and vissers,

Table III: Categorization of TIC Diagnosis of Malignant Spinal Lesions

\begin{tabular}{|l|c|c|c|c|c|c|}
\hline CNB diagnosis & \multicolumn{5}{|c|}{ Number of cases in TIC diagnostic categories } \\
\hline & Category 1 & Category 2 & Category 3 & Category 4 & Category 5 & Total \\
\hline Metastatic carcinoma & 2 & 0 & 0 & 1 & 13 & 16 \\
\hline Plasmacytoma & 2 & 0 & 0 & 1 & 0 & 3 \\
\hline Ewing sarcoma & 0 & 0 & 0 & 1 & 0 & 1 \\
\hline Chordoma & 0 & 0 & 0 & 1 & 0 & 1 \\
\hline Lymphoma & 0 & 0 & 1 & 0 & 0 & 1 \\
Malignant & 0 & 0 & 0 & 1 & 13 & 23 \\
\hline Total & 4 & 0 & 1 & 5 & & 0 \\
\hline
\end{tabular}
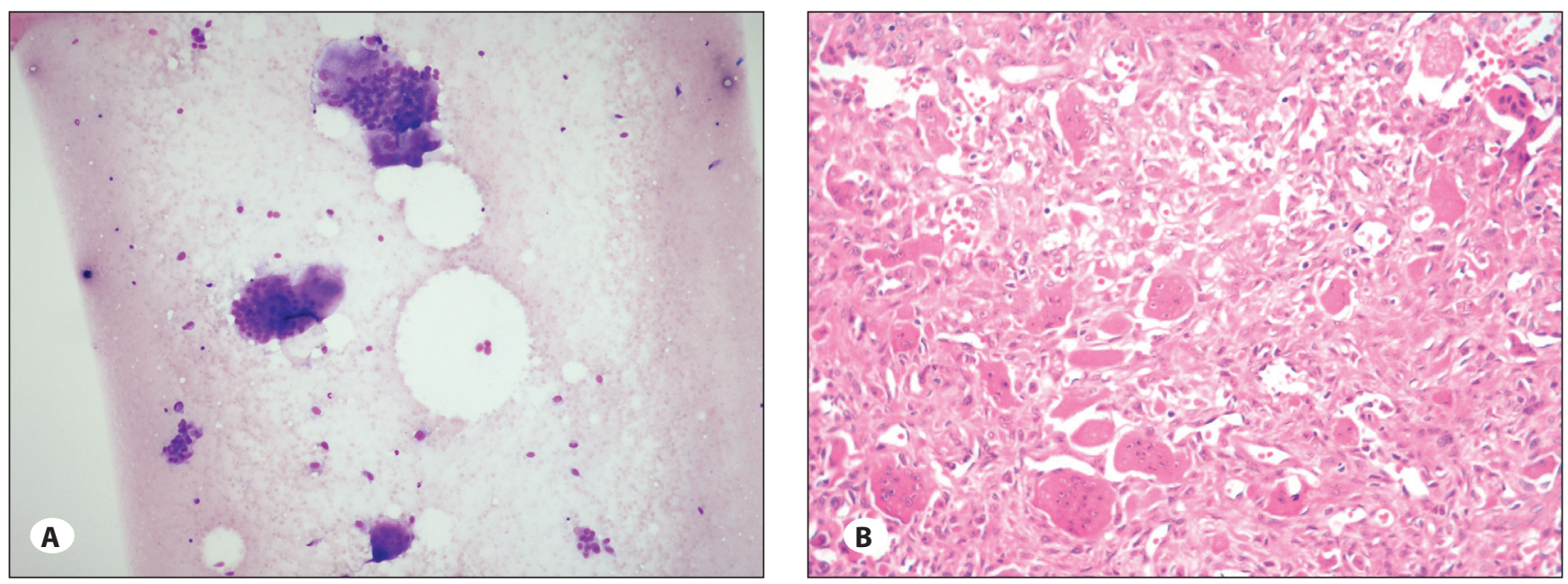

Figure 1: Giant cell tumor (A) Multinucleated giant cells on TIC (MGG, x200), (B) Histopathologic appearance of CNB (H\&E, x100).
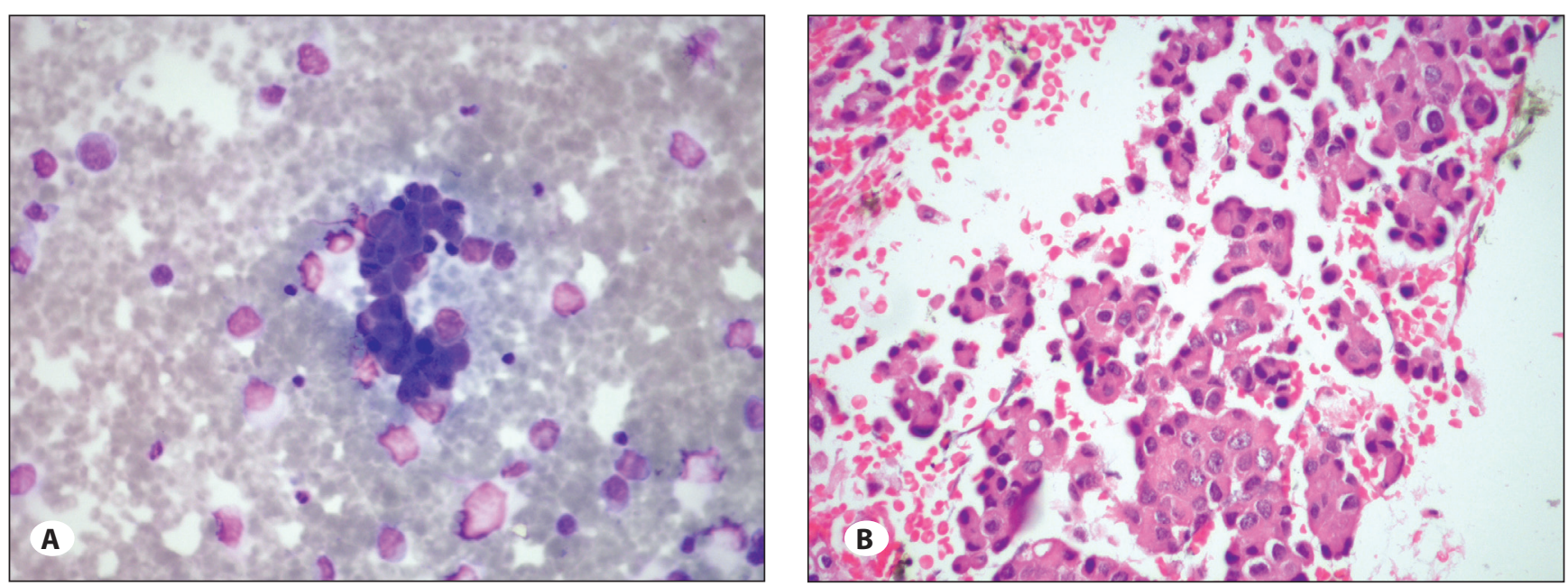

Figure 2: Papillary breast carcinoma (A) Papillary neoplastic cell groups on TIC (MGG, x200), (B) Histopathologic appearance of CNB (H\&E, x100). 
and the diagnostic accuracy is high. As imprints made from needle biopsies are used as a diagnostic tool in many other organs, it can also be used in conjunction with CNB in the diagnosis of spinal lesions.

For the spinal biopsy, the most frequent indication is the suspected metastasis (20). In our study, $28 \%$ of the cases were metastatic tumors. It was observed that the lesions in which TIC was diagnostically most useful were malignancies, being metastatic tumors particularly. On TIC, $88 \%$ of metastatic tumors were diagnosed as malignant and $82 \%$ of them could be typed. In the study of Rezanko et al., when TIC was taken into consideration instead of histopathologic assessment, the sensitivity of pathologic examination in metastatic tumors increased from $78.9 \%$ to $94.7 \%$ (16). However, this ratio decreased to $88.2 \%$ from $94.7 \%$ in our study because imprint preparations were acellular in 2 cases.

Nondiagnostic CNBs consisted of tissues belonging to muscle, adipose, connective, cartilage and intervertebral disc. The ratio of nondiagnostic CNBs was $45 \%$ which was a rather high percentage. A diagnostic finding was not determined in any of the imprints of nondiagnostic CNBs. Besides, imprints were nondiagnostic in 10 cases of diagnostic CNBs. The diagnosis in these 10 cases were metastatic carcinoma, plasmacytoma, giant cell tumor and inflammation. We thought that imprints were made from the wrong surface of the biopsy material, because in our study imprints of other cases with similar diagnosis had diagnostic findings. This finding shows us that the imprint should be made more carefully in such a way that it includes all sides of the CNB.

The H\&E and MGG stained slides were compared with regard to diagnostic yield and a significant difference was not observed. But MGG stained slides gave extra contribution to the evaluation of the chondroid matrix and nuclear detail.

We detected only 1 case in which malignancy was not present in CNB but was present in TIC. In the study of Rezanko et al. in which 101 cases were analyzed, there were 6 cases with benign CNB and malignant TIC (16). We believe the reason why TIC is malignant in cases with benign CNB was that the tip of the needle penetrates the lesion and then while the tissue is being removed the needle slips out of the lesion, but the lesional cells spread to the surface of the biopsy material. We did not find any study that would confirm our observation. Although there are opposite views $(9,4)$, some authors report that osseous blood clots were of high diagnostic value $(8$, 19). All these findings show that it is of vital importance to examine not only the tissue removed during the biopsy process but also all the cellular elements that may be brought with it. Moreover, some diagnostic findings that cannot be seen in CNBs because of blood or crushing artifact can be observed more obviously in their touch imprints.

In conclusion, we believe that examining TIC of CNB makes contribution not only to giving preliminary information, but also to the diagnosis. If representative sampling of the lesion is obtained, the cooperation between the clinician and the pathologist is established and precise imprint and careful cytopathologic examination are accomplished, the value of $\mathrm{TIC}$ will be higher in the diagnosis of spinal lesions.

\section{REFERENCES}

1. Ashizawa R, Ohtsuka K, Kamimura M, Ebara S, Takaoka K: Percutaneous transpedicular biopsy of thoracic and lumbar vertebrae--method and diagnostic validity. Surg Neurol 52(6):545-551, 1999

2. Ball RP: Needle (aspiration) biopsy. J Tenn Med Assoc 27: 203-206, 1934

3. Benoist M, Lenoir T, Guigui P: Epidemiology of spinal tumors. In: Gunzburg R, Szpalski M, Aebi M (eds), Vertebral Tumors. Philadelphia: Lippincott Williams \& Wilkins, 2008: 1-10

5. Brugieres P, Revel MP, Dumas JL, Heran F, Voisin MC, Gaston A: CT-guided vertebral biopsy. A report of 89 cases. J Neuroradiol 18(4):351-359, 1991

4. Berning W, Freyschmidt J, Ostertag H: Percutaneous bone biopsy, techniques and indications. Eur Radiol 6(6):875-881, 1996

6. Brugieres P, Gaston A, Heran F, Voisin MC, Marsault C: Percutaneous biopsies of the thoracic spine under CT guidance: Transcostovertebral approach. J Comput Assist Tomogr 14(3):446-448, 1990

7. Debnam JW, Staple TW: Needle biopsy of bone. Radiol Clin North Am 13(1):157-164, 1975

8. Hewes RC, Vigorita VJ, Freiberger RH: Percutaneous bone biopsy: The importance of aspirated osseous blood. Radiology 148(1):69-72, 1983

9. Jelinek JS, Murphey MD, Welker JA, Henshaw RM, Kransdorf MJ, Shmookler BM, Malawer MM: Diagnosis of primary bone tumors with image-guided percutaneous biopsy: Experience with 110 tumors. Radiology 223(3):731-737, 2002

10. Kattapuram SV, Khurana JS, Rosenthal DI: Percutaneous needle biopsy of the spine. Spine (Phila Pa 1976) 17(5): 561-564, 1992

11. Laredo JD, Bard M: Thoracic spine: Percutaneous trephine biopsy. Radiology 160(2):485-489, 1986

12. Lis E, Bilsky MH, Pisinski L, Boland P, Healey JH, O'Malley B, Krol G: Percutaneous CT-guided biopsy of osseous lesion of the spine in patients with known or suspected malignancy. AJNR Am J Neuroradiol 25(9):1583-1588, 2004

13. Metzger CS, Johnson DW, Donaldson WF, 3rd: Percutaneous biopsy in the anterior thoracic spine. Spine (Phila Pa 1976) 18(3):374-378, 1993

14. Murphy WA, Destouet JM, Gilula LA: Percutaneous skeletal biopsy 1981: A procedure for radiologists--results, review, and recommendations. Radiology 139(3):545-549, 1981

15. Ottolenghi CE: Aspiration biopsy of the spine. Technique for the thoracic spine and results of twenty-eight biopsies in this region and over-all results of 1050 biopsies of other spinal segments. J Bone Joint Surg Am 51(8):1531-1544, 1969 
16. Rezanko T, Sucu HK, Akkalp A, Tunakan M, Sari A, Minoglu $M$, Bolat $B$ : Is it possible to start the treatment based on immediate cytologic evaluation of core needle biopsy of the spinal lesions? Diagn Cytopathol 36(7):478-484, 2008

17. Rimondi E, Staals EL, Errani C, Bianchi G, Casadei R, Alberghini M, Malaguti MC, Rossi G, Durante S, Mercuri M: Percutaneous CT-guided biopsy of the spine: Results of 430 biopsies. Eur Spine J 17(7):975-981, 2008
18. Sucu HK, Cicek C, Rezanko T, Bezircioglu H, Ersahin Y, Tunakan M, Minoglu M: Percutaneous computed-tomography-guided biopsy of the spine: 229 procedures. Joint Bone Spine 73(5):532-537, 2006

19. Tehranzadeh J, Tao C, Browning CA: Percutaneous needle biopsy of the spine. Acta Radiol 48(8):860-868, 2007

20. Zileli M, Ozer FA: Omurilik ve Omurga Cerrahisi. Izmir: Meta Basım, 2002 